\title{
Therapeutic Trials in Multiple Sclerosis
}

\author{
J.H. Noseworthy, T.P. Seland and G.C. Ebers
}

Can. J. Neurol. Sci. 1984; 11:355-362

Several recently completed clinical trials are reported to demonstrate beneficial treatment with immunosuppressive therapy in multiple sclerosis (MS). The enthusiasm generated by these reports may motivate investigators to further such trials even in the face of the appreciable expense, time and risk involved. Of at least equal concern, clinicians are proceeding to treat individual MS patients without adequate evaluation of the claims. Critical appraisals of available data and proposals for future therapeutic endeavors therefore seem in order.

\section{Rationale for Immunosuppression}

The cause of MS is unknown, but a host of clinical, serological and pathological observations suggest that immunological abnormalities are important in the pathogenesis of the disease. Modification of the immune response in MS patients therefore seems a pertinent therapeutic route to pursue. Furthermore, animal models of MS including chronic experimental allergic encephalomyelitis (EAE) and virus-induced central nervous system (CNS) demyelination (Doherty and Sampson, 1981), while providing new insights into the basic mechanisms of demyelination and immune modulation, also have enabled screening of putative therapies before their application to clinical trials. There is evidence, for example, that EAE can be prevented or attenuated using a variety of immunosuppressive measures including cyclophosphamide (Paterson et al., 1969; Levine et al. , 1977), myelin basic protein (Alvord et al., 1979), Copolymer I (Teitelbaum et al. , 1974; Keith et al., 1979), interferon (Abreu, 1982), cyclosporin A (Borel et al., 1976; Levine et al., 1977; Bolton et al., 1982a and 1982b) and anti I-A antisera (Steinman et al., 1982). These studies provide experimental support to justify clinical trials of those agents in MS patients.

\section{Limitations of MS Clinical Trials}

The conduct of therapeutic trials in MS is notoriously complex. Investigators are hampered especially by inaccurate diagnosis, unpredictable progression and unreliable indices for monitoring disease activity.
The rigorous diagnostic criteria proposed by Schumacher et al. (1965) are difficult to realize, particularly in patients only mildly afflicted with MS. Recent refinements in imaging, evoked response and electrophoresis technologies have been applied in broader diagnostic guidelines (Poser et al., 1983).

The major objective of any clinical therapeutic trial must be to separate any effect of the proposed agent from the natural history of the disease. Those patients with recent evidence of disease progression have the best prospects for spontaneous remission, but also are those most likely to be entered into a clinical trial. Studies examining the influence of therapeutic agents on relapse rates must consider that relapse frequency declines with disease duration (McAlpine, 1972). Other factors to be considered in predicting outcome also have been examined: Duration of disease, development of a progressive course, age at onset, early cerebral involvement and the total number of relapses in the first two years vary directly with disease outcome (Noseworthy et al., 1983). The rate of progression of the disease eventually may prove to be the most important predictive variable early in the illness.

Investigators evaluating new therapeutic agents also should recall the very large placebo response $(69 \%)$ in the large cooperative study of ACTH in MS (Rose et al., 1970).

Any scheme designed to monitor disease activity by clinical assessment is inherently flawed by the well-recognized occurrence of extensive disease activity lacking clinical expression. Autopsy studies reveal widespread CNS demyelination even in patients known to have been asymptomatic through their lives (Georgi, 1961; Castaigne et al., 1981; Gilbert and Sadler, 1983; Phadke et al., 1983) and monosymptomatic relapses may be associated with multifocal lesions on enhanced CT-scans (Ebers et al., 1983). Furthermore, persisting sclerotic lesions will mask the appearance of new lesions involving the same CNS tracts. Finally, apparent clinical variations may not be reflecting disease changes at all but merely other independent variables introduced by changes in body temperature, intercurrent illness, emotional change and other poorly understood factors.

From the Department of Clinical Neurological Sciences, University Hospital, London, Ontario and the Department of Clinical Neurosciences, University of Calgary, Calgary

Reprint requests to: Dr. J.H. Noseworthy, Department of Clinical Neurological Sciences, University Hospital, 339 Windermere Road, London, Ontario, Canada N6A 5A5 
Since variations may occur independently of disease activity per se, investigators must avoid excessively fine scales in their attempts to measure them. Scales which rely heavily upon patient performance at the time of assessment (e.g. ambulation index - the ability to perform a motor task in a given period of time) may be particularly subject to these daily variations. Recognizing certain limitations, we favor the use of a combination of the recently proposed Expanded Disability Status Scale (EDSS) and the functional systems assessment of Kurtzke (1983).

While contemporary trials are limited by practical factors to utilization of these clinical indices, advances have been made toward more reliable measures of disease activity. A radioimmunoassay for the measurement of material cross-reactive with basic protein fragments $43-88$ detects approximately $70 \%$ of recent (less than two weeks) clinical relapses and is appropriately nonreactive in patients with no evidence of disease activity (Whitaker et al., 1980). However, this technique is limited by the requirement for serial lumbar punctures.

Evoked potential recordings will detect some asymptomatic lesions but may be time-consuming and costly. The number of evoked potential abnormalities increases with disease duration. Sequential use of these electrophysiological studies should provide an additional objective measure of disease activity.

Experience with high volume, delayed CT-scanning has shown that $12.5 \%$ of patients showing no clinical evidence of active disease still have enhancing abnormalities suggestive of ongoing demyelination (Ebers et al., 1983). NMR imaging (NMRi) is a sensitive technique for determining white matter abnormalities in patients with longstanding MS (Young et al., 1981; Lukes et al., 1983). NMRi may be particularly useful for detecting asymptomatic abnormalities in patients with chronic myelopathy and in patients with early MS (Noseworthy et al., 1984). Sequential studies suggest that NMRi may be useful to monitor the evolution of demyelination, since abnormal $T_{1}$ and $T_{2}$ relaxation times may recover with time in some patients (Noseworthy et al., 1984). It remains to be seen whether the age and activity of MS plaques can be characterized by quantitative NMR studies. Nevertheless, there is little doubt that this noninvasive technique will be useful for quantitating the extent of CNS involvement.

These and other problems in conducting clinical trials in MS were recognized and clearly outlined in the Schumacher report (1965). Guidelines for the design of clinical therapeutic studies in MS have been established (Brown et al., 1979) and were the subject of a recent international conference (Herndon and Murray, 1983).

\section{Clinical Trial Experience}

Tables 1 to 5 summarize the results of MS therapeutic trials performed since 1971. Pertinent previous studies included the ACTH cooperative trial alluded to above (Rose et al., 1970) and

Table 1: Clinical Trials with Azathioprine

\begin{tabular}{|c|c|c|c|c|c|c|c|}
\hline Investigator (Year) & ive Agent & $\mathbf{N}$ & Randomized & Controlled & Blinded & $\begin{array}{c}\text { (Years) } \\
\text { Mean Follow-up }\end{array}$ & Results \\
\hline Cendrowski (1971) & $\mathrm{Aza} / \mathrm{PI}$ & $\begin{array}{l}21(11-R R / \\
10-C P) / 9(7 R R \text {.CP) }\end{array}$ & - & + & - & $0.3-1.4$ & $\begin{array}{l}\text { No effect in reducing } \\
\text { relapses in steroid } \\
\text { non-responders. }\end{array}$ \\
\hline $\begin{array}{l}\text { Silberberg et al. } \\
\text { (1973) }\end{array}$ & Aza & 16(10-RR.6-CP) & - & 一 & - & 1.25 & $\begin{array}{l}5 / 6 \mathrm{CP} \text { patients progressed. } \\
\mathrm{RR} \text { patients no benefit. }\end{array}$ \\
\hline Aimard et al. (1977) & Aza & $\begin{array}{l}\text { 38-RR } \\
27-\mathrm{CP}\end{array}$ & - & $\begin{array}{c}78 \text { historical } \\
-\end{array}$ & - & 5 & $\begin{array}{l}\text { RR - fewer relapses, few } \\
\text { progress } \\
\text { CP - no benefit. }\end{array}$ \\
\hline Frick et al. (1977) & Aza & $\begin{array}{l}\text { 58-RR } \\
21-\mathrm{CP}\end{array}$ & $\begin{array}{l}- \\
-\end{array}$ & $\begin{array}{l}\text { self } \\
\text { self }\end{array}$ & - & $\begin{array}{l}2.25 \\
2.8\end{array}$ & $\begin{array}{l}\text { RR - fewer relapses, } \\
\text { fewer progress } \\
\text { CP - 1/3 no longer progress. } \\
\text { None improved. }\end{array}$ \\
\hline Oger et al. (1977) & Aza & 75-RR 。 & - & self & 一 & 3 & $\begin{array}{l}\text { Relapse rate falls, } 30 / 75 \\
\text { no relapses, no progression. }\end{array}$ \\
\hline Rosen (1979) & $\begin{array}{l}\text { Aza } \\
\text { Aza/Pl }\end{array}$ & $\begin{array}{c}\text { 85-CP } \\
20-\mathrm{CP} / 22-\mathrm{CP}\end{array}$ & $\overline{+}$ & $\begin{array}{l}\text { historical } \\
\text { Yes }\end{array}$ & - & $\begin{array}{c}6-14 \\
3-6\end{array}$ & $\begin{array}{l}<10 \% \text { wheelchair } \\
\text { restricted. Wheelchair } \\
\text { dependence in } 9 \% \text { treated } \\
\text { vs. } 65 \% \text { control. }\end{array}$ \\
\hline $\begin{array}{l}\text { Patzgold et al. } \\
\text { (1982) }\end{array}$ & Aza/NT & $\begin{array}{c}\text { 22-RR/31-RR } \\
32-R P / 20-R P \\
6-C P / 4-C P\end{array}$ & $\begin{array}{l}+ \\
+ \\
+\end{array}$ & $\begin{array}{l}+ \\
+ \\
+\end{array}$ & $\begin{array}{l}- \\
- \\
-\end{array}$ & $\begin{array}{l}2 \\
2 \\
2\end{array}$ & $\begin{array}{l}\text { RR - no effect on relapse rate. } \\
\text { RP - deterioration slowed. } \\
\text { CP - deterioration continues. }\end{array}$ \\
\hline
\end{tabular}

\begin{tabular}{llllll}
\hline AZA & Azathioprine & NT & No treatment & CP & Chronic progressive \\
PI & Placebo & RR & Relapsing-remitting & RP & Relapsing-progressive
\end{tabular}


the negative studies of long term use of corticosteroids in preventing disease progression (Fog, 1965; Miller et al., 1967).

A number of deficiencies become evident on review of these treatment trials. Most involve only small numbers of patients with brief follow-up. Many fail to categorize the patient subgroups as relapsing-remitting, chronic progressive, or other. Most trials were entirely uncontrolled, used only historical controls (i.e. retrospectively matched), or used patients as their own controls to predict the expected outcome (e.g. relapse rate, rate of progression) according to the progression of the illness prior to treatment.

Most of the studies were not blinded. Admittedly, certain treatment modalities such as cyclophosphamide or plasmapheresis may limit or preclude patient blinding. However, even though blinding of the evaluator may be equally difficult, this should be attempted. Furthermore, even when proper randomization was accomplished, stratification techniques were generally ignored. As a consequence, important differences occurred in the treatment and control groups in terms of age of onset and age of entry (Hauser et al., 1983), age at entry and duration of disease (Seland et al., 1974), degree of disability (Mertin et al., 1983) and relapse rate (Jacobs et al., 1982).
A number of reports suggest that intensive immunosuppression may benefit MS patients (Tables 1 to 3). Four studies (Aimard et al., 1977; Frick et al., 1977; Oger et al.; 1977; Mertens et al., 1982) using historical controls suggest that chronic azathioprine helps patients with relapsing-remitting disease. One prospective controlled study (the second limb of Rosen's 1979 study) suggests that some patients with chronic progressive disease may respond to chronic azathioprine treatment. Three studies (Cendrowski et al., 1971; Silberberg et al., 1973; Swinburn et al., 1973) failed to find improvement with azathioprine administration. Aimard (1977) found azathioprine to be of no benefit to patients with chronic progressive disease. Patzgold (1982) could detect only a marginal effect in patients with relapsingprogressive disease with this agent. In other studies (Table 2) antilymphocyte globulin (ALG) appeared to add little to the effects of azathioprine and corticosteroids.

Further support for immunosuppressive therapy comes from the well-designed study by Hauser et al. (1983). Fifty-eight patients with progressive disease were randomized to treatment with ACTH alone, with a combination of ACTH, oral cyclophosphamide and plasmapheresis, or with ACTH and high dose intravenous (IV) cyclophosphamide (Table 3). The most

Table 2: Clinical Trials with Azathioprine in Combination with Other Agents

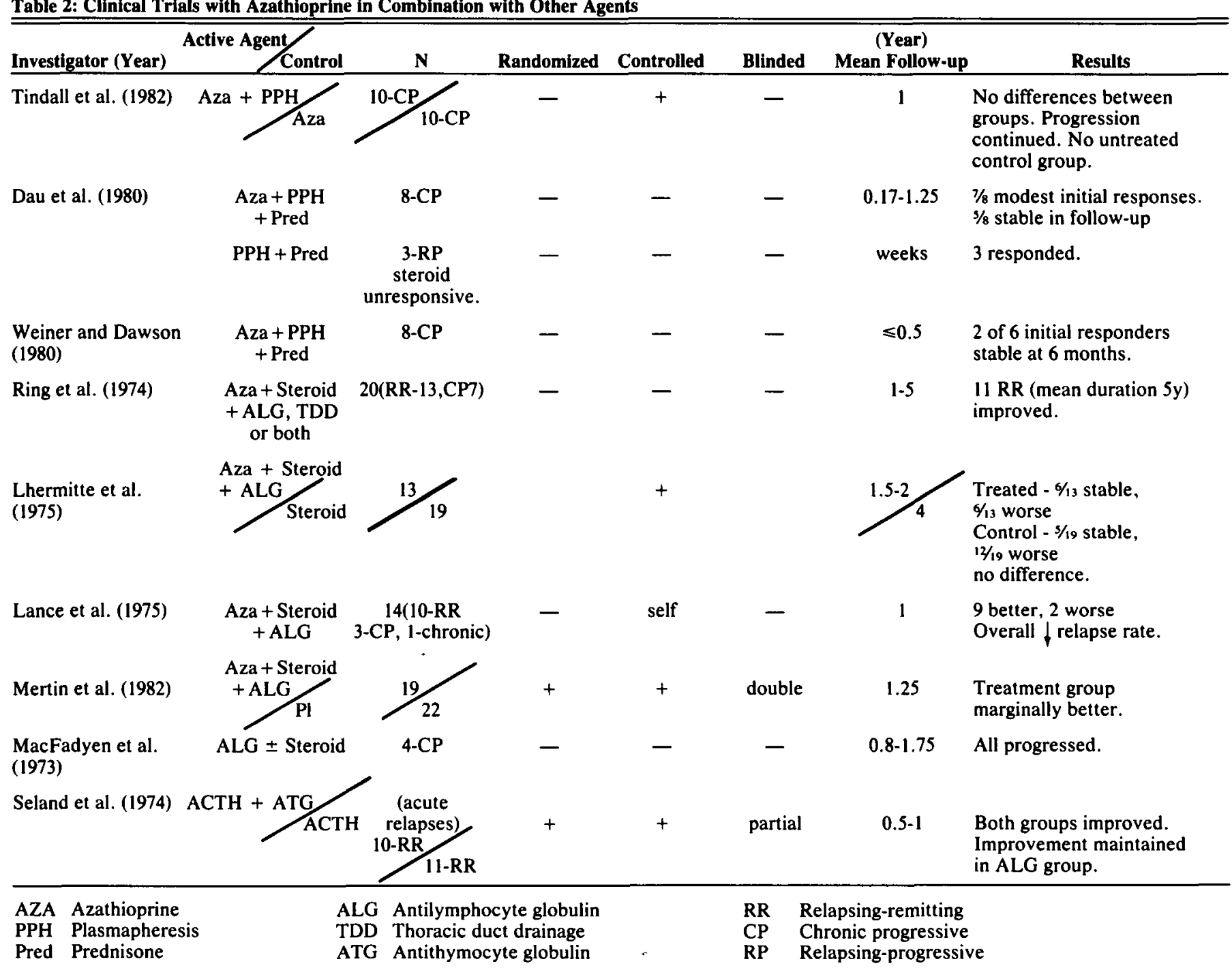


Table 3: Clinical Trials with Cyclophosphamide

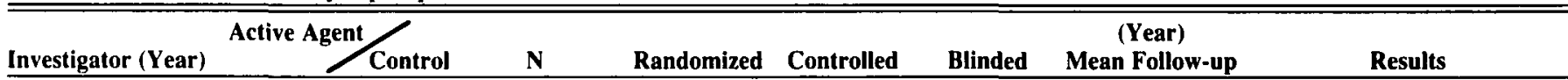

Cendrowski (1973) CY $\mathrm{Cteroid/Steroid}$

20(17-RR

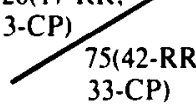

$\mathrm{CY}^{*}+$ Pred

$55-\mathrm{CP}$ 3-CP)

Hommes and Lamers (1977)

Gonsette and

Delmotte (1977)

CY

$$
\begin{gathered}
\text { 140(134-RR. } \\
\text { 6-CP) }
\end{gathered}
$$

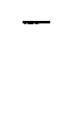

$\begin{array}{cc}\text { historical } & - \\ \text { self } & -\end{array}$

Theys et al. (1981)
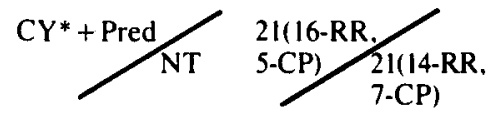

Hauser et al. (1983)

$$
\begin{aligned}
& \text { ACTH (control) } \\
& \text { ACTH + CY } \\
& \text { ACTH + CY* } \\
& \text { + PPH }
\end{aligned}
$$

20-CP

20-CP

18-CP

Khatri et al. (1983) $\mathrm{CY}^{*}+$ Pred

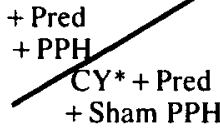

53-CP total
CY

(IX/month) X6

Huston et al. (1983)

ide (intravenous)

CY Cyclophosphamide (intrave
CY* Cyclophosphamide (oral)

Pred Prednisone

\section{NT No treatment}

PPH Plasmapheresis
1 month - 1.7 No difference between groups. RR possibly better than $C P$.

$2-2.7$

$46 \%$ improved. $85 \%$ progression slowed. 2nd. year some again progressed at a slower rate.

RR - $62 \%$ stabilized or improved from relapse. $C P$ - 4 improved and stabilized 1-2 y.

No difference.

Deterioration continued.

$4 / 2 n$ stabilized.

$16 / 2 n$ stabilized.

$11 / 16$ progressed year 2-3.

\%/18 stabilized.

PPH patients often significantly improved. Sham PPH patients no change or continued progression.

0.3-0.8 CP - 7/8, RR - all stabilized or improved.

\section{RR Relapsing-remitting \\ CP Chronic progressive}

dramatic responses were seen in the third group in which sixteen of twenty patients were reported to be stabilized or improved at one year. Unfortunately, eleven of these sixteen responders again developed progressive disease in the second or third year of follow-up. Critics have noted that the study was not blinded, that it lacked an untreated control group, that the follow-up was insufficient, and that the psychological "placebo" effect of the alopecia produced by the cyclophosphamide was not considered (Fishbeck, 1983). Furthermore, most or all of the patients in the study presumably had been previously treated unsuccessfully with ACTH or corticosteroids and therefore patients randomized to receive $\mathrm{ACTH}$ alone were aware that they were receiving an agent which failed to benefit them in the past. This may have influenced their treatment expectations and may have magnified the difference in outcome between this control group and patients receiving the "active" agent (cyclophosphamide \pm plasmapheresis). Finally, since moderately disabled patients may spontaneously vary by more than a single point over brief intervals on the ambulation index, a change of this magnitude may not necessarily reflect a change in the disease (Miller, 1983). Even given those qualifications, this study provides some corroborative evidence for earlier reports (Hommes et al., 1977; Gonsette et al., 1977) of delayed deterioration in patients who initially respond to immunosuppressives. Further studies are under way to determine if repeated attempts at induction of remission are profitable with these agents.
A recent preliminary report from Khatri et al. (1983) suggests a rather dramatic response of patients with chronic progressive MS to relatively long term weekly plasmapheresis combined with daily oral cyclophosphamide and alternate day prednisone. Further reports on this patient group are eagerly anticipated.

Few studies of immunosuppressive agents provide evidence that the treated patients were in fact functionally immunosuppressed. The best indices for immunosuppression are not well established and determination of a wide panel is costly and at risk of excluding the relevant index. For this and other reasons, treatment schedules and dosages remain arbitrary.

The published experiences with levamisole and with transfer factor are summarized in Table 4. Six of seven levamisole studies failed to demonstrate any response. Another (Dau et al., 1976) indicated that five of seven patients treated with levamisole deteriorated over a brief period raising the concern that this drug, known to be an immunostimulant, may even have adversely affected the natural history of the disease. Two recent reports suggest that relapsing-remitting patients treated with transfer factor may do slightly better than control patients (Lamoureux et al., 1981) particularly if they are mildly affected and followed for as long as one or two vears (Basten et al., 1980). Other studies have failed to show any benefit from transfer factor.

Table 5 outlines several miscellaneous trials. There is no evidence for a beneficial effect from linoleic acid, from 


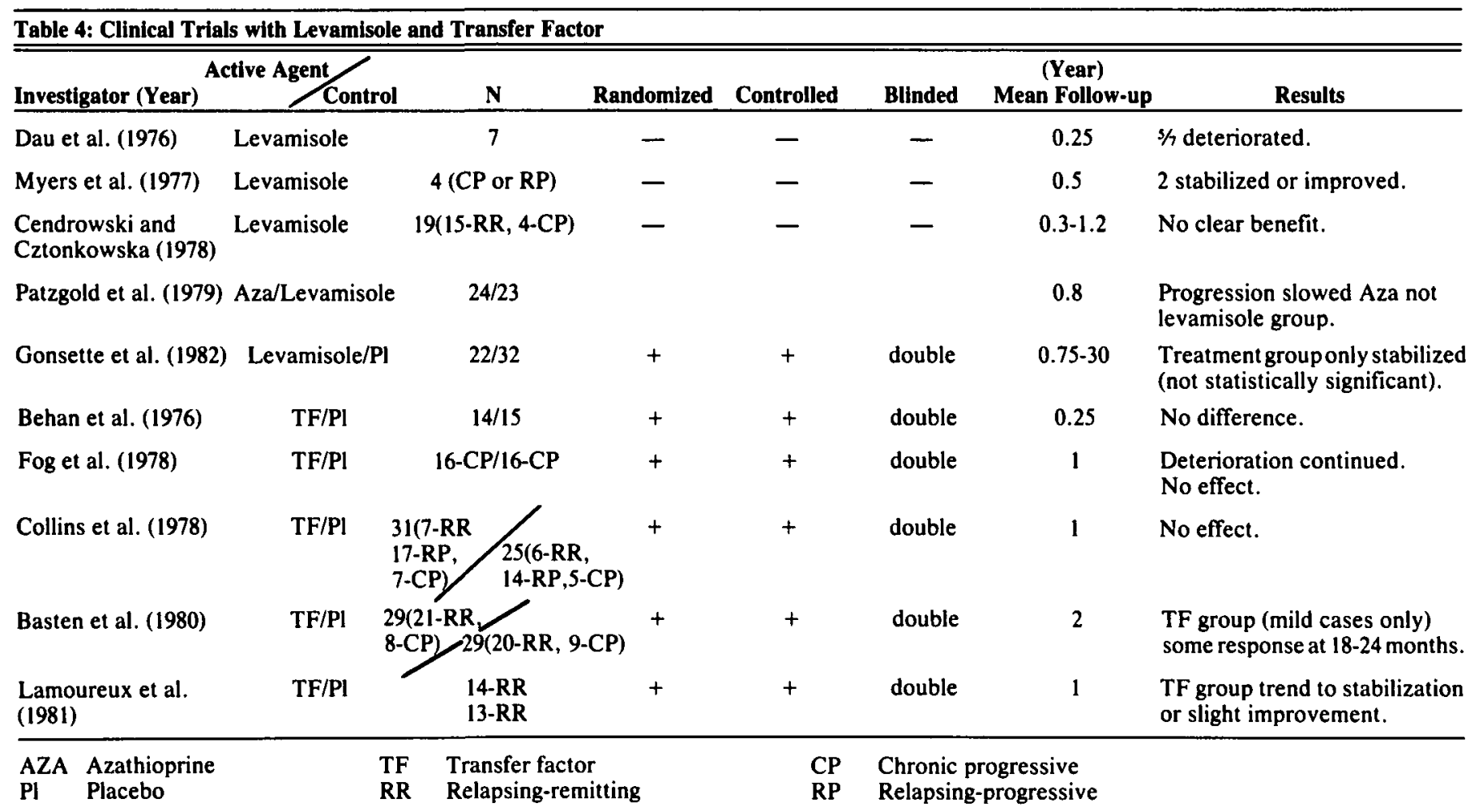

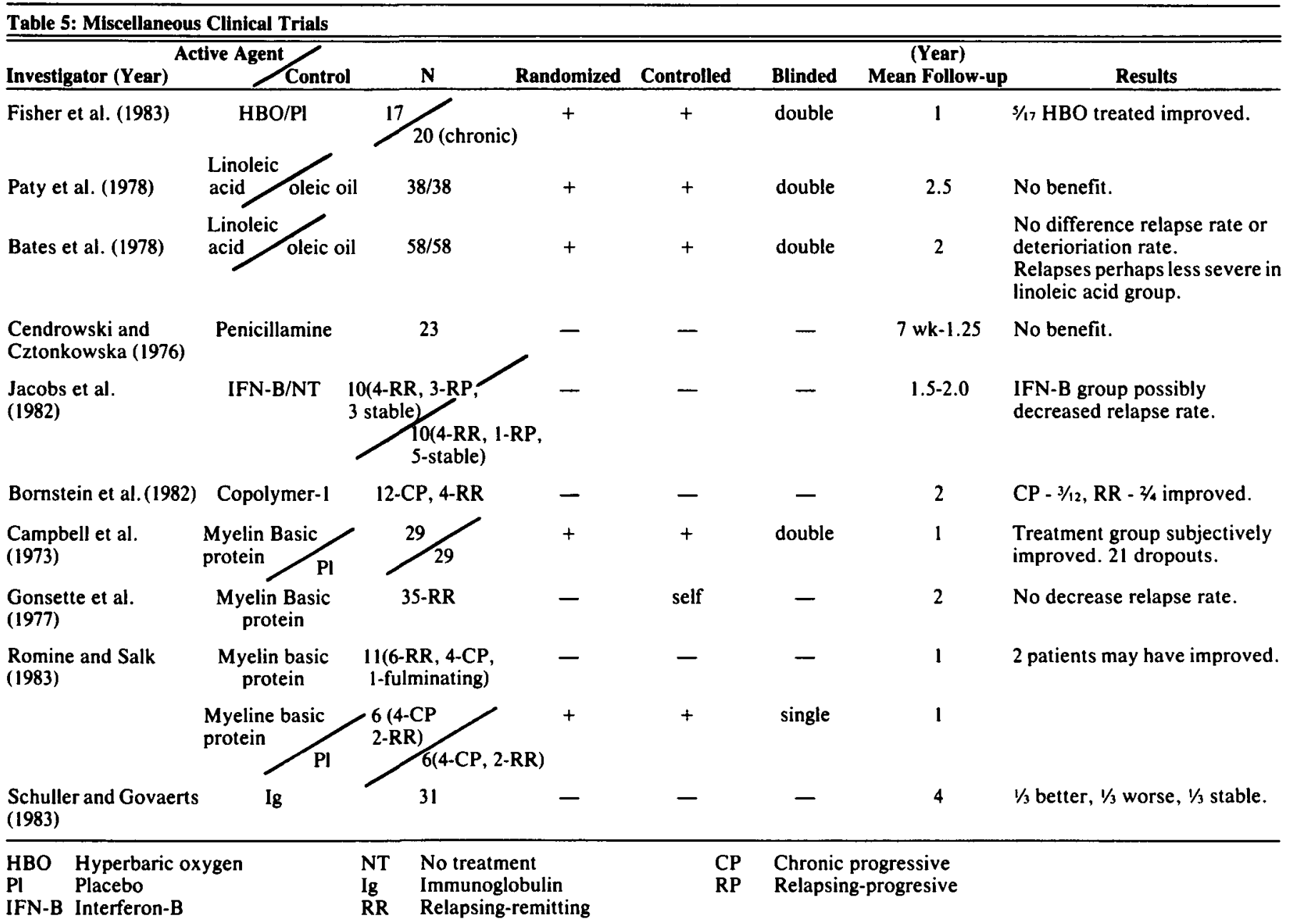


penicillamine, or from human immunoglobulin. The controversial results of the study of intrathecal interferon (IFN) by Jacobs et al. (1982) await confirmation of the sixteen further IFN trials currently in progress. Fisher et al. (1980) reported that 5/17 chronic MS patients were improved twelve months following a series of hyperbaric oxygen (HBO) treatments but the disability status score (DSS) changes were not mentioned. The overall DSS change for the treatment group at one year was rather modest $(0.59 \pm 1.06)$, the $p$ value of $<.006$ notwithstanding. A further eight clinical trials are under way to assess the efficacy of $\mathrm{HBO}$.

A number of trials are currently in progress to evaluate the effect of cyclosporin A on MS. A fungal metabolite with low myelocytoxicity, cyclosporin $A$ is a potent immunosuppressive with action against proliferating $\mathrm{T}$ cells and, to a lesser degree, against $B$ cells. As such, it has major immunosuppressive effects on delayed-type hypersensitivity, cell mediated cytolysis and graft versus host responses and has predictably had a major impact in the field of organ transplantation (White, 1982). Its possible efficacy in patients with posterior uveitis (Nussenblatt et al., 1983) and in newly-diagnosed juvenile diabetes mellitus (Stiller et al., 1983) and its ability to prevent or attenuate EAE suggests that cyclosporin A may have some effect in modulating a secondary immune response presumably operative in MS. Furthermore, it is possible that future generations of cyclosporin will prove to be more useful and less toxic.

Thus, existing evidence justifies a degree of optimism. Finding that immunosuppressives may be beneficial in some MS patients suggests that this disease is immunologically-mediated. Certainly further carefully-designed, randomized studies are needed and a number of these are in progress including trials evaluating interferon (sixteen trials), HBO (eight), azathioprine (eight), lymphocytapheresis (eight), cyclophosphamide (seven), cyclosporin A (three), plasma exchange (three), total lymphoid irradiation (three), protease inhibitors, transfer factor, staphyloccal phage lysate and monoclonal antibody versus DR2. Future trials should adhere to the guidelines of the Brown Committee (1979), should attempt to incorporate the markers of disease activity reviewed above and should implement stratification techniques at the time of randomization. The authors are currently developing a large scale, Canadian multicenter placebo-controlled trial to assess and compare the efficacy of the most promising current immunosuppressive protocols in progressive MS following these guidelines.

\section{Potential Risks of Immunosuppressive Therapy}

The potential hazards, both immediate and long term, inherent in nonspecific immunosuppression must be carefully considered before administration, particularly to those patients with early disease. Because of the risks, and pending more definitive results, immunosuppression should be restricted to those patients identified as having a poor prognosis. A major concern has been the de novo occurrence of malignancy in immunosuppressed patients. This problem has been particularly well defined in recipients of human allografts (a group of patients which does differ in several important ways from MS patients). Between two and eleven percent of immunosuppressed renal allograft recipients will develop a tumor (Penn, 1979). Of 3000 patients treated with cyclosporin $A$ to date, $0.5 \%$ have developed a lymphoma but experience with this drug is early and the relationship to drug dosage, duration of treatment and association with other immunosuppressives is not clear (Penn, 1982; EditorialLancet, 1983).

There are further reasons for caution. Cyclophosphamide, and to a lesser extent other immunosuppressives, inactivates suppressor $\mathrm{T}$ cells $\left(\mathrm{T}_{\mathrm{S}}\right)$ precursors and experimentally may lead to loss of immunological tolerance (Polak et al., 1974). Mice made resistant to EAE by the generation of $T_{S}$ cells again become susceptible to this disease following pretreatment with low dose cyclophosphamide (Lando et al., 1979). If active suppressor mechanisms are responsible for remission of MS, it remains possible that elimination of rapidly-dividing $T_{S}$ precursors by cyclophosphamide could lead to immune enhancement with acceleration of immunologically mediated CNS injury. One could argue therefore that immunosuppressives should be reserved for patients with active disease in whom there is already evidence of disturbed immune regulation.

\section{Future Considerations}

It is unlikely that the currently available agents will provide long-term definitive treatment in this disease. Clearly more disease-specific agents will emerge as new immunosuppressives are developed and as more is understood of the etiology and pathogenesis of MS. If, for example, a restricted number of MS-initiating antigens could be identified, it might then be possible to suppress the disordered immune response in an antigen-specific fashion. Conceivably one could induce specific tolerance with in-vivo administration of these purified antigens. In this vein, early attempts to induce antigen-specific tolerance with myelin basic protein have been disappointing (Campbell et al., 1973; Gonsette et al., 1977; Romine and Salk, 1983). However, the results of a preliminary study with Copolymer I, a synthetic polypeptide immunologically cross-reactive with myelin basic protein and capable of suppressing EAE, have encouraged investigators to proceed with a full scale clinical trial (Bornstein et al., 1982).

Another approach could take advantage of the exquisite specificity of the immune response. Unique structural determinants, termed idiotypes, exist on the antigen recognition site of T cells, B cells and antibodies (Oudin and Michel, 1963; Kunkel et al., 1963). These idiotypes are shared by $T$ and $B$ cells which react against the same antigenic determinants (Binz and Wigzell, 1975) and thus distinguish cells and cell products from others in the immune system. As such, they are immunogenic and the targets of immune regulation. When idiotype-expressing cells proliferate upon exposure to antigen, an anti-idiotypic immune response is generated against these idiotypes. In turn, anti-idiotypic determinants are immunogenic and similarly stimulate an immune response directed against them (antianti-idiotypic). This chain of events continues until the immune response is down-regulated. There is good evidence that this series of immunological events, initially termed the "network theory of the immune response" by Jerne (1974), occurs in response to an immune challenge and is an important regulatory mechanism (see review by Rodkey, 1980). In the future, it may be possible to influence the immune response in MS by modifying idiotype/anti-idiotype interactions in an antigen-specific way (Ebers, 1982).

Pending substantiation of the numerous promising preliminary reports, only cautious optimism can be offered for the use of immunosuppressive agents in progressive MS. Patients who are clinically stable should be offered only close monitoring and 
appropriate supportive treatment measures. When disease progression is obvious clinically immunosuppressive measures should be offered only with the full realization of the potential risks and of the limited evidence for their benefit. Optimally, these patients should be treated within the carefully supervised confines of formal clinical trials.

\section{REFERENCES}

Abreu SL (1982) Suppression of experimental allergic encephalomyelitis by interferon. Immuno Commun. 11: 1-7.

Aimard G, Confavreux C, Trouillas $P$, et al. (1977) Our experience of azathioprine treatment in multiple sclerosis. In: Delmotte, P., Hommes, O.R., Gonsette, R. (Editors): Immunosuppressive Treatment in Multiple Sclerosis, Ghent, Belgium, European Press. pp. 38-45.

Alvord EG, Shaw C, Hruby S (1979) Myelin basic protein treatment of experimental allergic encephalomyelitis in monkeys. Ann. Neurol 6: $469-473$.

Basten A, Pollard JD, Stewart JD, Frith JA, McLeod JG, Walsh JC, Garrick R, Van Der Brink CM (1980) Transfer factor in treatment of multiple sclerosis. Lancet (8201). 931-934.

Bates D, Fawcett PRW, Shaw DA, Weightman D (1978) Polyunsaturated fatty acids in treatment of acute multiple sclerosis. B. Med. J. ii: 1390-1391.

Behan PO, Durward WF, Melville ID, McGeorge AP, Behan WMH (1976) Transfer factor therapy in multiple sclerosis. Lancet. i: 988-990.

Binz H, Wigzell H (1975) Shared idiotypic determinants on B and T lymphocytes reactive against the same antigenic determinants. I. Demonstration of similar or identical idiotypes on $\mathrm{IgG}$ molecules and T-cell receptors with specificity for the same alloantigens. J. Exp. Med. 142: 197-211.

Bolton C, Borel JF, Cuzner ML, Davison AN, Turner AM (1982a) Immunosuppression by cyclosporin $\mathrm{A}$ of experimental allergic encephalomyelitis. J. Neurol. Sci. 56: 147-153.

Bolton C, Allsopp G, Cuzner ML (1982b) The effect of cyclosporin A on the adaptive transfer of experimental allergic encephalomyelitis in the Lewis rat. Clin. Exp. Immunol. 47: 127-132.

Borel JF, Feurer C, Gubler HU, Stahelin H (1976) Biological effects of cyclosporin A: A new anti-lymphocytic agent. Agents Actions 6: 468-475.

Bornstein MB, Miller AI, Teitelbaum D, Arnon R, Sela M (1982) Multiple sclerosis: Trial of a synthetic polypeptide. Ann. Neurol. 11: 317-319.

Britton S, Palacius R (1982) Cyclosporin A - usefulness, risks and mechanism of action. Immunological Rev. 65: 5-22.

Brown JR, Beebe GW, Kurtzke JF, Loewenson RB, Silberberg DH, Tourellotte WW (1979) The design of clinical studies to assess therapeutic efficacy in multiple sclerosis. Neurology 29: 3-23.

Campbell B, Vogel PJ, Fisher E, Lorenz R (1973) Myelin basic protein administration in multiple sclerosis. Arch. Neurol. 29: 10-15.

Castaigne P, Lhermitte F, Escourolle R, Hauw JJ, Gray F, Lyon-Caen $O$ (1981) Les Scleroses en plaques asymptomatiques. Rev. Neurol. (Paris). 137: 729-739.

Cendrowski WS (1971) Therapeutic trial of imuran (azathioprine) in multiple sclerosis. Acta Neurol. Scandinav. 47: 254-260.

Cendrowski WS (1973) Combined therapeutic trial in multiple sclerosis. Hydrocortisone hemisuccinate with cyclophosphamide or cytosine arabinoside. Acta Neurol. Belgica 73: 209-219.

Cendrowski W, Cztonkowska A (1976) Penicillamine in multiple sclerosis. Acta Neurol. Scandinav. 54: 281-286.

Cendrowski W, Cztonkowska A (1978) Levamisole in multiple sclerosis, with special reference to immunological parameters. A pilot study. Acta Neurol. Scandinav. 57: 354-359.

Collins RC, Espinoza LR, Plank CR, Ebers GC, Rosenberg RA, Zabriski JB (1978) A double-blind trial of transfer factor vs. placebo in multiple sclerosis patients. Clin. Exp. Immunol., 33: 1-11.

Dau PC, Johnson KP, Spitler LE (1976) The effect of levamisole on cellular immunity in multiple sclerosis. Clin. Exp. Immunol. 226: 302-309.

Dau PC, Petajan JH, Johnson KP, Panitch HS, Bornstein MB (1980) Plasmapheresis in multiple sclerosis: Preliminary findings. Neurology 30: $1023-8$.
Doherty P, Sampson E (1982) Murine models of multiple sclerosis, Nature 299: 106-107.

Ebers GC (1982) A study of CSF idiotypes in MS. Scand. J. of Immunol. 16: $151-162$

Ebers GC, Vinuela FV, Feasby T, Bass B (1984) Multifocal CT enhancement in MS. Neurology 34: 341-346.

Editorial (1983) Cyclosporin and neoplasia. Lancet. i: 1083.

Fishbeck KH (1983) Letter: N. Engl. J. Med. 309: 239-240.

Fisher BH, Marks M, Reich T (1983) Hyperbaric-oxygen treatment in multiple sclerosis. A randomized placebo-controlled, double-blind study. N. Engl. J. Med. 308: 181-6.

Fog $T(1965)$ The long-term treatment of multiple sclerosis with corticoids. Acta Neurol. Scand. 41. (Suppl. 13, Part 2): 473-484.

Fog T, Raun NS, Pederson L, Kam-Hansen S, Mellerup E (1978) Long-term transfer-factor treatment for multiple sclerosis. Lancet i: 851.853 .

Frick E, Angstwurm H, Blomer R et al. (1977) Long-term treatment of multiple sclerosis with azathioprine. In: Delmotte, P., Hommes, O.R., Gonsette, R. (Editors): Immunosuppressive Treatment in multiple sclerosis. Ghent, Belgium, European Press, pp. 88-98.

Georgi W (1961) Multiple Sklerose. Pathologisch-anatomische befunde multipler skerose bei Klinisch nicht diagnostizierten Krankheiten. Schqiz Med Wsclv. 91: 605-607.

Gilbert JJ, Sadler M (1983) Unsuspected multiple sclerosis. Arch Neurol. 40: $533-536$

Gonsette RE, Delmotte P (1977) Intensive immunosuppression with cyclophosphamide in multiple sclerosis. J. Neurol. 214: 173-181.

Gonsette RE, Delmotte P, Demonty L (1977) Failure of basic protein therapy for multiple sclerosis. J. Neurol. 216: 27-31.

Gonsette RE, Demonty L, Delmotte P, de Cock W, Verhaegen H, Symoens J (1982) Modulation of immunity in multiple sclerosis: A double-blind levamisole-placebo controlled study in 85 patients. J. Neurol. 228: 65-72.

Hauser SL, Dawson DM, Lehrich JR et al. (1983) Intensive immunosuppression in progressive multiple sclerosis. N. Eng. J. Med. 308 173-180.

Herndon RM, Murray TJ (1983) Proceedings of the International Conference on therapeutic trials in multiple sclerosis. Arch. Neurol. 40: $663-710$.

Hommes OR, Lamers KJB (1977) Immunosuppressive treatment in chronic progressive multiple sclerosis. In: Delmotte, P., Hommes, O.R., Gonsette, R. (Editors): Immunosuppressive Treatment in multiple sclerosis. Ghent, Belgium. European Press, pp. 48-64.

Huston DP et al. (1983) Letter. N. Eng. J. Med. 309: 241.

Jacobs L, O'Malley J, Freeman A, Murawski J (1982) Intrathecal interferon in multiple sclerosis. Arch. Neurol. 39: 609-615.

Jerne NK (1974) Towards a network theory of the immune system. Ann. Immunol. (Inst. Pasteur). 125C: 373-389.

Keith AB, Arnon R, Teitelbaum D, Caspary EA, Wisniewski HM (1979) The effect of COP I, a synthetic polypeptide on chronic relapsing experimental allergic encephalomyelitis in guinea pigs. J. Neurol. Sci. 42: 267-274.

Khatri BO, Harrington GJ, Schmoll D, McQuillen MP (1983) A doubleblind randomized controlled study of immunosuppressive drug therapy (IDT) with plasmapheresis (PP) in chronic progressive multiple sclerosis. Neurology. 33 (Suppl. 2): 178-179.

Kunkel HG, Mannik M, Williams RC (1963) Individual antigenic specificity of isolated antibodies. Science 140: 1218-1219.

Kurtzke JF (1983) Rating neurologic impairment in multiple sclerosis: An expanded disability status scale(DSS). Neurology. 33: 1444-1452.

Lamoureux G, Cosgrove J, Duquette P, Lapierre $Y$, Jolicoeur R, Vanderland F (1981) A clinical and immunological study of the effects of transfer factor on multiple sclerosis patients. Clin. Exp. Immunol. 43: 577-584.

Lance EM, Kriemer M, Abbosh J, Jones VE, Knight S, Medawar PB (1975) Intensive immunosuppression in patients with disseminated sclerosis. I. Clinical response. Clin. Exp. Immunol. 21: 1-12.

Lando Z, Teitelbaum D, Arnon R (1979) Effect of cyclophosphamide on suppressor cell activity in mice unresponsive to EAE. J. Immunol, 123: $2156-2160$.

Levine S, Sowinski R (1977) Suppression of the hyperacute form of experimental allergic encephalomyelitis by drugs. Arch. Int. Pharmacodyn. 230: 309-318. 
Lhermitte F, Marteau R. de Saxce H (1975) Traitement de la sclerose en plaques par le serum antilymphocytaire. In: Immunopathologie due Systeme Nerveux. Schuller, M.E. (editor): Paris, INSERM. 1341: 281-300.

Lukes SA, Crooks LE, Aminoff MJ, Kaufman L, Panitch HS, Mills C, Norman D (1983) Nuclear magnetic resonance imaging in multiple sclerosis. Ann. Neurol. 13: 592-601.

MacFadyen DJ, Reeve CE, Bratty PJA, Thomas JW (1973) Failure of antilymphocytic globulin therapy in chronic progressive multiple sclerosis. Neurology. 23: 592-598.

McAlpine D, in McAlpine D, Lumsden CE, Acheson ED (1972) Multiple Sclerosis: A reappraisal. Second Edition, Churchill Livingston, Edinburgh. p. 205.

Mertens HG, Dommasch D (1977) Long-term study of immunosuppressive therapy in multiple sclerosis, comparison of periods of the disease before and during treatment. In: Delmotte, P., Hommes, O.R., Gonsette, R. (Editors): Immunosuppressive Treatment in Multiple Sclerosis. Ghent, Belgium, European Press, pp. 198-211.

Mertin J, Kremer M, Knight SC et al. (1982) Double-blind controlled trial of immunosuppression in the treatment of multiple sclerosis: Final report. Lancet. 2: 351-354.

Miller AE (1983) Letter. N. Eng. J. Med. 309: 240.

Millar JHD, Vas CJ, Noronha MJ, Liversedge LA, Rawson MD (1967) Long-term treatment of multiple sclerosis with corticotrophin. Lancet 2: 429-31.

Myers LW, Ellison GW, Levy J, Holevoet MI, Ma BI, Tourtellotte WW (1977). Evaluation of levamisole as a treatment for multiple sclerosis. Neurology 27: 363 .

Noseworthy JH, Paty DW, Wonnacott T, Ebers GC (1983) The markers of prognosis in multiple sclerosis. Ann. Neurol 14: 114

Noseworthy JH, Buonanno FS, Kistler JP, Rosen B, New PFJ, Brady TJ (1984) True three-dimensional nuclear magnetic resonance neuroimaging in multiple sclerosis. (Submitted, Neurology).

Nussenblatt RB, Rook AH, Wacker WB, Palestine AG, Scher I, Gery I (1983) Treatment of intraocular inflammatory disease with cyclosporin A. Lancet. (8344). 235-238.

Oger J, Deugnier Y, Hinault P, Sabouraud O (1977) Experience of long term immunosuppressive therapy in multiple sclerosis. In: Delmotte, P., Hommes, O.R., Gonsette, R. (Editors): Immunosuppressive treatment in Multiple Sclerosis. Ghent, Belgium. European Press. pp. 100-113.

Oudin J, Michel M (1963) Une nouvelle forme d'allotypie des globulins $\gamma$ du serum de lapin apparement liée a la fonction et a la spécificité auticorps. C.R. Acad. Sci. 257: 805-808.

Paterson PY, Hanson MA (1969) Cyclophosphamide inhibition of experimental allergic encephalomyelitis and cellular transfer of the disease in Lewis rats. J. Immunol. 103: 1311-1316.

Paty DW, Cousin HK, Read S, Adlakha K (1978) Linoleic acid in multiple sclerosis: Failure to show any therapeutic benefit. Acta Neurol. Scandinav. 58: 53-58.

Patzgold U, Haller P, Haas J, Pocklington P. Dreicher H (1979) Therapie der multiplen sklerose mit levamisole und azathioprine. Nervenarzt. 49: 285-294.

Patzgold U, Hecker H, Pocklington P (1982) Azathioprine in treatment of multiple sclerosis. J. Neurol. Sci. 54: 377-394.

Penn I (1982) Malignancies following the use of cyclosporin A in man. Cancer Surveys. 1: 621-624.

Penn I (1982) Malignancies following the use of cyclosporin A in man. Cancer Surveys. 1: 621-624.

Phadke JG, Best PV (1983) Atypical and clinically silent multiple sclerosis. A report of 12 cases discovered unexpectedly at necropsy. J. Neurol. Neurosurg. Psychiat. 46: 414-421.
Polak L, Turk JL (1974) Reversal of immunological tolerance by cyclophosphamide through inhibition of suppressor cell activity. Nature (Lond.). 249: 654.

Poser CM, Paty DW, Scheinberg L et al. (1983) New diagnostic criteria for multiple sclerosis: Guidelines for research protocals. Ann. Neurol. 13: 227-231.

Ring J, Lob G, Angstwurm H, Brass B, Backmund H, Seiffert J, Coulin K, Frick E, Mertin J, Brandel W (1974) Intensive immunosuppression in the treatment of multiple sclerosis. Lancet (7889). 1093-1096.

Rodkey LS (1980) Autoregulation of immune responses via idiotype network interactions, Microbiol. Rev. 44: 631-659.

Romine JS, Salk J (1983) A study of myelin basic protein as a therapeutic probe in patients with multiple sclerosis. In: Hallpike JF, Adams CWM, Tourtellotte WW (Editors): Multiple Sclerosis. Williams and Wilkins, Baltimore. pp. 621-630.

Rose AS, Kuzma JW, Kurtzke JF et al. (1970) Cooperative study in the evaluation of therapy in multiple sclerosis. ACTH vs placebo. Neurology 20 (Suppl.) 1-59.

Rosen JA (1979) Prolonged azathioprine treatment of nonremitting multiple sclerosis. J. Neurol. Neurosurg. Psychiat. 42: 338-344.

Schuller E, Govaerts A (1983) First results of immunotherapy with immunoglobulin $\mathrm{G}$ in multiple sclerosis patients. Eur. Neurol. 22: 205-212.

Schumacher GA, Beebe G, Kibler RF et al. (1965) Problems of experimental trials of therapy in multiple sclerosis: Report by the panel on the evaluation of experimental trials of therapy in multiple sclerosis. Ann. NY Acad. Sci. 122: 552-568.

Seland TP, McPherson TA, Grace M, Lamoureux G, Blain JG (1974) Evaluation of antithymocyte globulin in acute relapses of multiple sclerosis. Neurology 24: 34-40.

Silberberg D, Lisak R, Zweiman B (1973) Multiple sclerosis unaffected by azathioprine in pilot study. Arch. Neurol. 28: 210-212.

Steinman L, Rosenbaum JT, Sriram S, McDevitt HO (1981) In vivo effects of antibodies to immune response gene products; Prevention of experimental allergic encephalitis. Proc. Natl. Acad. Sci. U.S.A. 78: 7111-7114

Stiller CR, Laupacis A, Dupre J, Jennar MR, Keown PA, Rodger W, Wolfe BMJ (1983) Cyclosporin for treatment of early type 1 diabetes: preliminary results. N. Eng. J. Med. 308: 1226-1227.

Swinburn WR, Liversedge LA (1973) Long-term treatment of multiple sclerosis with azathioprine. J. Neurol. Neurosurg. Psychiat. 36: 124-126.

Teitelbaum D, Webb C, Bree M et al. (1974) Suppression of experimental allergic encephalomyelitis in rhesus monkeys by a synthetic basic copolymer. Clin. Immunol. Immunopathol. 3: 256-262.

Theys P, Gosseye - Lissoir F, Ketelaer P, Carton H (1981) Short-term intensive cyclophosphamide treatment in Multiple Sclerosis. J. Neurol. 225: 119-133.

Tindall RSA, Walker JE, Ehle AL, Near L, Rollins J, Becker D (1982) Plasmaphresis in multiple sclerosis. Prospective trial of pheresis and immunosuppression verses immunosuppression alone. Neurology. 32: 739-743.

Weiner HL, Dawson DM (1980) Plasmapheresis in multiple sclerosis: Preliminary study. Neurology (Minneap.). 30: 1029-33.

Whitaker JN, Lisak RP, Bashir RM, Fitch OH, Seyer JM, Krance R, Lawrence JA, Ch'ien LT, O'Sullivan PO (1978) Immunoreactive myelin basic protein in the cerebrospinal fluid in neurological disorders. Ann. Neurol. 7: 58-64.

White DJG (Editor) Cyclosporin A (1982) New York, Elsevier Press.

Young IR, Hall AS, Pallis CA, Bydder GM, Legg NJ, Steiner RE (1981) Nuclear Magnetic resonance imaging of the brain in multiple sclerosis. Lancet (8255) 1063-1066. 